Torben Kragh Grodal:

\title{
Tendenser i nyere fiktionsanalyse: Kommunikation, ekspression og historisering
}

Der er et væld af retninger på markedet til beskrivelse af fiktion. Der er samtidig en stadig strid mellem forskellige teoretiske skoler, stridigheder der ofte hænger sammen med forskellige opfattelser af, hvad der er ønskværdig fiktion og kunst. Fra den hjemlige scene har vi i de sidste årtier haft modsætninger mellem historiserende betragtningsmåder (ideologikritik, socialhistorie, mentalitetshistorie etc.) og betragtningsmåder der opfattede værkerne som personlige eller overpersonlige udtryk. Og der har været modsætninger mellem strukturelle og grammatologiske og andre såkaldt post-strukturelle synspunkter. Disse modsætninger har været intimt sammenvævede med gamle problemstillinger såsom: er værket en repræsentation af en udenforliggende virkelighed eller ej. Andre skillelinjer går mellem at analysere værkerne set fra et afsendersynspunkt, som kunstnerudtryk, eller at analysere dem udfra en receptionssynsvinkel, udfra et modtagersynspunkt, men konflikterne mellem disse to synsvinkler har været relativt behersket, mere behersket end diskussionen af, hvorvidt afsenderpostitionen skulle diskuteres udfra et psykoanalytisk synspunkt eller ej. Mindre fredeligt har derimod samlivet været mellem de tilgange, der tog deres udgangspunkt i beskæftigelsen med massekulturen og massekommunikationen over for de tilgange, der tog udgangspunkt i beskæftigelsen med de mere eliteprægede produkter.

Diskussionerne og modsætningerne er ikke blevet mindre opladede fordi man som regel har opfattet modsætningerne som mere end blotte metodiske valg. De forskellige valg har for de respektive tilhængere haft vidtforskellige politiske eller livsanskuelsesmæssige implikationer. Af den måde disse stridigheder og diskussioner er udformede på, kunne man få det indtryk, at der var tale om forskellige opfattelser af de samme objekter og fænomener. I det efterfølgende vil jeg 
imidlertid argumentere for, at selv om der på nogle punkter er tale om faktiske forskelligheder i de fremherskende metoders og skolers opfattelser, er der samtidig også tale om at de ikke taler om det samme objekt, de forskellige retninger undersøger forskellige aspekter af et fænomenkompleks.

\section{Kommunikation og ekspression}

Jeg vil tage mit udgangspunkt i de ikke-historiske eller kun svagt historiske teoridannelser for senere at vende tilbage til historieproblemet. Diskussionen af mere immanente grundspørgsmål har i de sidste årtier særlig været præget af to hinanden bekrigende retninger, strukturalismen og den såkaldte poststrukturalisme, med navne som grammatologi, dekonstruktion osv. Begge retninger er opgør med naive afspejlingsteorier, de beskæftiger sig med kulturelle, menneskeformede udtryk. Men strukturalismen ser de tekstlige og visuelle betydningsproblemer fra en kommunikationssynsvinkel, betydning er et socialt fænomen, der opstår i samvirket mellem mindst to og som regel mange individer. De poststrukturelle strømninger (og deres forgængere i fænomenologien) ser derimod betydningsproblemet udfra en ekspressionssynsvinkel og fra en individuel eller subindividuel synsvinkel. ' Betydningen opstår for dem i ensomme skabere, hvadenten der er tale om et individ der skriver/maler eller et der læser/ser. Der ses nemlig ikke noget radikalt skel mellem de to former for ekspression. ${ }^{2}$

For strukturalismens fader, Saussure, var der ingen tvivl om sprogets sociale og kommunikative karakter. Han tog sit analytiske udgangspunkt i tegnet, som han så som en socialt foretaget sammenføjning af udtryk og indhold. For ham var sproget selvfølgeligt et middel til kommunikation, udtrykkene var midler til at transportere et indhold fra ét individ til et andet. Og for at dette kan lade sig gøre, må individerne besidde faste sammenhænge mellem udtryk og indhold. Hvad glæde havde man af at sige: hent gaflen, hvis modtageren af udtrykket forbandt udtrykket med indholdet 'pindsvin' og hentede et sådant. Saussure underforstod selvfølgelig at man ville benytte sproget til gensidig forståelse. $\mathrm{Og}$ han underforstod derfor at man ikke ville benytte det til misforståelse, tilsløring, kommunikationsbrud eller selvudtryk.

Saussures strukturalisme var mest rettet mod forståelse af udtrykssystemerne, f.eks. lyd, som et system af forskelle. Indholdet bekymrede han sig ikke så meget om, han havde kun brug for indholdet til at 
skelne mellem betydningsbærende og betydningsløse udtryksforskelle. Hans forståelse af betydning var tydeligvis baseret på referentialitet. Et tegn var en sammenkobling af et udtryk og et indhold, en mental forestilling, og de to sider af tegnet var så tæt sammenknyttede som forsiden og bagsiden af et stykke papir. Men forestillingen fik igen sin stabilitet ved at repræsentere noget 'virkeligt'. Tegnet hest, sammenknytningen af udtryk og indhold fik sin stabilitet ved at der derude i verden fandtes vrinskende hovdyr. Den senere strukturalisme overførte struktur-systemet til også at omfatte indholdet, og gjorde sig hyppigt ikke klart, hvilke problemer der var ved at overfore den Saussure'ske strukturalisme til indholdsplanet. ${ }^{3}$

De fleste af Saussures forudsætninger svarer fint til common sense, vi lærer sproget i kommunikation med andre mennesker, vi forsøger at forstå hvad den anden mener; et givet udtryk betyder noget bestemt og vi kommunikerer indtil 'vi forstår hinanden'. Det gælder selvfølgelig også for billeder, barnet arbejder med sin tegning indtil dets omgivelser finder den acceptabel, f.eks. ved at sige at den ligner. En anden måde at beskrive kommunikation på er, at sige, at der via forskellige udtrykssystemer forsøges frembragt intersubjektiv identitet og repræsentation. De udtrykssystemer der er udformet ved en meget stor kommunikationsintensitet mellem mange mennesker er hyppigt dem der er lettest beskrivbare udfra strukturalistiske principper. Netop den intersubjektive kommunikation frembringer strukturelle systemer og faste koblinger mellem udtryk og indhold. Strukturelle analyser har da også med forkærlighed kastet sig over de centrale dele af dagligsproget og, indenfor fiktionens område, over de store massekulturelle genrer, som folkeeventyr, reklamebilleder og kriminalfilm.

Fra grammatologisk side er en tegnopfattelse, der bygger på begreber som identitet og repræsentation, blevet voldsomt angrebet. Den strukturelle tegnopfattelse ses som del af en metafysisk, ideologisk og fejlagtig tradition. Således har Derrida brugt megen energi på at efterspore, hvorledes forestillinger om identitet og repræsentation i en række tekster er blevet legitimeret med religiøse og metafysiske forestillinger. ${ }^{4}$ Bl.a. fordi repræsentation for ham flyder i ét med sand, ikke-arbitrær afspejling. For de fleste mennesker er en sådan kritik selvfølgelig ligegyldig, idet deres opfattelse af sprogets og billedernes repræsentative funktion er praktisk-kommunikativ: de be'r om en kop kaffe og får en kop kaffe, de tegner noget hvormed de forbinder 'bil', og deres omverden siger 'nå, du har tegnet bil', eller de tegner en nonfigurativ tegning, og omverdenen tilkendegiver at de forstår at der er tale om en nonfigurativ tegning. 
De fleste mennesker kan være ligeglade med om denne praktiske kommunikation og repræsentationsforestilling er udtryk for hvad Derrida har kaldt 3000 års vestlig metafysik. Problemet med den Saussurske tegnopfattelse ligger ikke primart $i$ representationsforestillingen, men derimod i, at den kun beskriver den gennemsocialiserede kommunikation, en kommunikation hvor alle deltagerne har fåt opbygget identiske koblinger mellem udtryk og indhold, mellem udtryk og repræsentation. Den beskriver ikke dynamiske, individuelle betydningsforhold. Når en person møder et udtryk, kommer dette ikke fikst og færdigt med tilhørende indhold. Bestemte indlæringssituationer, feed-back osv. kan udvirke, at et givet udtryk for forskellige individer tenderer mod at henvise til samme indhold. At afsender og modtager får tilordnet samme indhold til identiske udtryk, er imidlertid en tendens $i$ kommunikationen, der fremmes af nogle faktorer og modvirkes af andre. Og heroverfor står en ganske modgående tendens, som jeg vil kalde ekspressionens tendens til individuel eller lokal opbygning af sammenhænge mellem udtryk og indhold.

Grundlaget for tendensen mod en ustabil og privat betydning er særligt stærkt blevet påpeget af Derrida. Det består i det forhold, at udtrykkene og indholdene ikke har samme status. I forståelsen af og skabelsen af betydning må vi altid gå fra udtryk til indhold. Såvel når vi modtager som når vi afsender meddelelser er udtrykket mere afgrænset og stofligt end indholdet. Man kan udstøde lyden gulk og dermed mene noget bestemt uden at andre har en chance for at gætte betydningen, selvom de udmærket opfanger udtrykket. Man kan se et billede af Mona Lisa og tænke på en hårbalsam. Man kan udstøde lyde eller tegne krusseduller, der ikke for afsenderen giver nogen afgrænset mening og betydning. Man kan læse bøger eller se billeder, hvor kun enkelte ord eller billedfragmenter giver nogen afgrænset mening og betydning.

Man kan derfor se den pegende finger som et billede på udtrykket. Fingeren er på én gang et fysisk nærvær og en pegen på noget anden end den selv. Netop den pegende finger kan betyde hvadsomhelst, og hvad den betyder afhænger både af fingerens kontekst, den person der retter den, de genstande der omgiver den, og af de iagttagere, der ser den. Pegningen markerer blot en rettethed mod noget hinsides fingeren selv. Og som fingeren kun kan betyde et bestemt subjekts betyden, sålænge forbindelsen med kroppen ikke er hugget over, således er også udtrykkets ekspressive side bundet til subjektet. Man kan fă andres tegn og bileder ind gennem sanser og ind $\mathrm{i}$ bevidstheden, men betydningstillæggelsen, tydningen, kan kun foregå som en subjektiv pegende bevægelse. Når vi ser andres pegen, får vi derfor to 
meddelelser: 1. Den anden betyder, udtrykker sig, og 2. Den anden peger på, betyder noget bestemt. Og denne bestemthed kan vi kun komme $\mathrm{i}$ besiddelse af ved at sætte os i den andens sted, identificere os med den pegende person, dennes pegen og dennes synsvinkel. Mens kommunikationen som grundlag har bevægelsen mod entydighed, baseret på intersubjektiv identitet - fælles, præfabrikerede 'kroppe', 'fingre' og 'synsvinkler' - kan ekspressionen gå den modsatte vej. Den kan henlede opmærksomheden på den krop, et subjekt, der peger og udsiger. Ligeledes kan sociale ord og billeder oplades med ubestemt subjektiv betydning. Eller man laver nye formudtryk som kastes ud i omverdenen, og derved skabes der eventuelt nye betydninger hos modtageren. Ved at beskæftige sig med sproget som dynamisk proces og udtrykket som en fysisk størrelse, hvis bestemmelse kun kommer i stand ved et socialt arbejde, har 'poststrukturalister' foretaget en vigtig supplering af den strukturelle, statiske systemtankegang. Ethvert nyt udtryk vil imidlertid snart komme til at indgå i en kommunikationssammenhæng (ligesom det som forskel, som afvigelse fra altid allerede eksisterende norm indgår $i$ en sådan). Man vil forsøge at 'forstå' udtrykket, hermeneutisk at indleve sig i det og eventuelt tillægge det en fast og afgrænset betydning. Sådanne sociale og kommunikative processer, der forudsætter et ønske om fælles forståelse og fælles repræsentation, vil poststrukturalisten se på med stor mistænksomhed.

Netop enkeltindividets brug af udtrykkene har været genstand for poststrukturalisternes interesse. Mens strukturalisterne har interesseret sig for det perfekt socialiserede ord, har de kastet sig over kommunikationsbruddene. Poststrukturalisterne har interesseret sig for alle de steder, hvor det fortolkende subjekt står overfor udtrykkenes gådefulde stoflighed og udfører en individualistisk eller anarkistisk læse/skrivepraksis. Denne ekspression er selvfølgelig det modsatte af representation, for repræsentation er forsøget på at skabe intersubjektiv identitet. $\mathrm{Og}$ poststrukturalister interesserer sig som sagt ikke for kommunikation. De interesserer sig ikke som strukturalisterne for de meget 'sociale' udtryk som reklamebilleder og folkeeventyr, men derimod for superindividualistiske, næsten idiolektale tekster. De har făet stor udbredelse hos de kunstnere, der oplever deres arbejde som selvudtryk, f.eks. som protest mod de sociale betydninger, der opleves som ideologi og tvang.

Poststrukturalister som Derrida og Paul de Man har rødder i fænomenologien; således er Derrida's kritik af nærværstænkningen en kritik af fænomenologien inden for fænomenologiens præmisser. Fænomenologer som Husserl 'satte verden i parentes', de beskæftigede sig med enkeltindividets bevidsthedsmæssige forhold til omverdenen 
med udelukkelse af den intersubjektive interaktion. Og for Derrida og de Man er skrift og tekst altid forstået fænomenologisk-hermeneutisk: problemstillingerne ses 'i læselampens skær', i beskrivelsen af den ensomme læsers eller tænkers forholden sig til skrift og tekst. Hvordan skrift og tekst indgik i mere omfattende praksisformer i forhold til medmenneske og objektverden er som for den Husserlske fænomeno$\log$ 'sat uden for parentesen'.

De individualistiske træk i poststrukturalismen bringer romantikken i erindring. Der er dog forskel på nutidens dekonstruktionisters og tidligere tiders romantikeres forestillinger om kunstnerisk selvekspression. Mens romantikerne opfattede det personlige udtryk som et udtryk der havde et indre, personligt og oprindeligt indhold, så opfatter dekonstruktionisterne udtrykket som oprindelsesløst, som en altid allerede givet materiale, som leger $\mathrm{i}$ bevidstheden og som bevidstheden kan lege med, og kan lade pege i mange forskellige retninger. P.t. er det førromantiske æstetiske begreb om den fromme depersonaliserede oplevelse, begrebet om det Sublime, dog ved at fortrænge 60ernes mere anarkistisk-dynamiske negationsspil. Vægten lægges mere på den subjektive effekt end på processen.

Strukturalister og poststrukturalister taler begge om sprog og betydning, og derved tilsyneladende om samme fænomener. Men faktisk taler de om to polære og komplementære aspekter af udtrykket, henholdsvis om udtrykkets sociale og kommunikative aspekt og om dets individuelle, ekspressive aspekt. ${ }^{5}$ De to aspekter forudsætter gensidigt hinanden, og spiller bestandig sammen. Det forekommer indlysende at hævde, at stadig flere mennesker bliver inddraget i stadig mere omfattende kommunikationssystemer, fra global massekommunikation til uddannelsessystemer, fra kunstmuseer med tilhørende kataloger og kommentarer til internationale litterære systemer. Og samtidig tilnærmes livsvilkårene globalt af den sociale udvikling. Der er således stærke kræfter, der arbejder for at skabe kommunikation, skabe kollektive representationer og identiteter. Men det forekommer lige så indlysende at hævde, at der er stærke kræfter, der trækker i den modsatte retning. Dels er enkeltindividerne blevet løsrevet fra tidligere samfunds mere snævre kommunikationssammenhænge med tilhørende kontekster. Dels skaber samspillet mellem de moderne mangfoldigheder af forskellige udtrykssystemer ved gensidig interferens en stadig strøm af individuelle eller lokale innovationer. Den periode i 20erne og 30erne hvor begreber som énsretning, gleichschaltung, opstod, var samtidig præget af et mylder af betydningseksperimenter, der konstruerede nye betydninger, bl.a. ved en dekonstruktion af gamle betydningssystemer.

Men hvis strukturalisme og poststrukturalisme behandler komple- 
mentære aspekter af betydningsfænomenet, hvorfor lever de to retninger så i blodig konfrontation fremfor i fredelig sameksistens? En del af forklaringen ligger i de stærke ideologiske vurderinger der knyttes til modsætningen mellem at opfatte betydning som et socialt fænomen, der reproduceres integreret $i$ sociale systemer overfor at betragte betydning som et individuelt eller subindividuelt fænomen, præget af et stadigt kreativt betydningsarbejde. Kunst- og betydningsteorierne opfattes ikke alene som neutrale, beskrivende teorier, men også som normative, som æstetikker og som livsanskuelser. Dertil er der knyttet nogle oplevelsesmæssige forhold. Så længe et kunstværk besidder ekspressionens underbestemte henvisning, så længe opleves det med et spændt liv. Kommunikationens bestemmelse af udtrykkene ses derfor som en afspænding af kunstværket, der dræber det dynamiske, det udsigende og krative subjekt ved at lade det opgå som blotte spor i en objektiv-ydre og statisk verden. Det anede og gådefulde er for mange mere tiltrækkende end det åbenlyse. Kommunikation, fastlæggelse af betydning - enten i form af éntydighed eller i form af systematisk flertydighed, ændrer oplevelsens karakter. Den fremkalder nu bestemte tankebaner og forestillinger. Fra et privat modtagersynspunkt kan man vælge udelukkende at beskæftige sig med ekspressionen, med den umættede, underbestemte henvisning, der for mange er indbegrebet af det æstetiske. Fra en videnskabelig synsvinkel må man imidlertid foretage en helhedsbeskrivelse af de æstetiske fænomener, både beskrive deres effekt og beskrive de kommunikative betydningssystemer hvori denne effekt skabes. Subjektivitet og intersubjektivitet er komplementære, men funktionelt sammenhængende systemer.

\section{Den andrede samfundsmassige rolle for tekst og billede}

Tekst- og symbolindlæringen har gennem de sidste århundreder fået stigende betydning i socialisering og social orientering. Tidligere foregik langt større dele af den sociale adfærd ved en meget konkret interaktion: hvis man stjal fik man hugget hånden af; hvis man skulle være bonde eller ridder gik man ud og kikkede på nogle sociale forbilleder. Man snakkede, kikkede på kalkmalerier og fortalte historier, men disse 'tekstlige' aktiviteter fungerede hele tiden indlejret $\mathrm{i}$ andre interaktionssammenhænge. Mundtlig, visuel eller skriftlig tekst var et supplement.

$\mathrm{Nu}$ tenderer udviklingen i den modsatte retning. Den fysiske og konkrete interaktion bliver et supplement, symbolindlæringen kommer til at 
indtage en stadig mere central rolle. Social indordning bliver indlæring af sociale tekster, indlæring af bestemte repræsentationsformer og af tekstlige identiteter. Den sociale opdragelse bliver i højere og højere grad centreret om skolen og dens forlængelser, og af indlæringen af læsning, skrivning og bestemte sociale repræsentationsformer. Det gælder selvfølgelig ikke bare normalsprog og normalbilleder, kunst, litteratur og musik har altid haft en didaktisk rolle. Tilsyneladende skete der ganske vist i slutningen af det 18 . århundrede en vis splittelse mellem på den ene side de nyttige, sociale tekster, der var indrettet til didaktiske formål, og på den anden side de æstetiskprivate tekster, der i højere grad skulle fungere som selvudtryk for privatindividerne. Men samtidig blev disse astetiske produkter hurtigt et dannelsespensum og et centralt led i socialiseringen. Eleverne lærte at fortolke og udlægge de æstetiske tekster efter sociale normer: Homer mente sikkert..., Laokoongruppen har følgende symbolik..., Goethe ville hermed sige... osv. Hvis tilskueren ved synet af Dali's brændende giraffer eller gummiure, spørger, hvad pokker meningen kan være, vil undervisningssystemet m.v. give en række svar, der kan læres og hvori der kan stilles eksamensspørgsmål. Undervisningen kan indlære entydighed: værk X betyder dette og hint. Men den kan også med stor éntydighed indlære tvetydigheden. Ved eksamensbordet skal man éntydigt kunne fastslå at en given sætning er præget af mangetydighed. Når derfor poststrukturelle teoridannelser fungerer i bedste velgående som universitetsdiscipliner med tilhørende eksamensspørgsmål, er det en ironisk kommentar til omfanget af betydningsteorierne. Kommunikationens gevaldige bestemmelse af betydningerne kan opleves som et stadig drab på den underbestemte ekspressions livfulde fylde, men det er den historiske og institutionelle udformning af bestemmelsen der overhovedet giver ubestemtheden dens betydning(er).

Indlæringen af social orden og social sammenhæng er således $\mathrm{i}$ stigende grad blevet forskudt fra den konkrete til den symbolske verden, ligesom forsøgene på løsnelse af samme sociale orden også foregår i den symbolske verden. Tidligere tideres konkrete oprør mod konkrete myndighedsinstanser såsom fædre og fyrster, kanaliseres ind $\mathrm{i}$ en kamp mod faste sociale betydninger og repræsentationer. Modsætninger mellem det sociale og det individuelle udspiller sig omkring forståelsen af de betydende teksters karakter.

Spændingen mellem kommunikation og ekspression, forstået som en modsætning mellem tvang og frihed, forstærkes af, at ikke blot er der sket en bevægelse i retning af, at de symbolske tekster spiller en stadig større rolle i den styrede socialisering; også i den ustyrede 
socialisering og i opbygningen af omverdenen kommer symbolske tekster til at spille en afgørende rolle. De sidste tiår har set en sand syndflod af såvel fiktion som kulturhistoriske fremstillinger, der kredser om det forhold, at den industrielle vækst, medieeksplosionen o.s.v. har afklippet forbindelsen til en udenfor liggende virkelighed. Tidligere kunne man sige at et billede var et billede af naturen, nu kan man - ifølge dette synspunkt, der særligt er blevet fremført af Jean Baudrillard - næsten hævde, at naturen er en konkret realisering af billede, film eller reklame. Naturen fungerer kun som en ideologisk forankring af de kulturelle billeder og symboler ved at være en nostalgisk hævdelse af en oprindelse og mening. Baudrillards position er en unødig nostalgisk syndefaldsmyte: han kan kun finde betydning og mening, hvis den menneskelige verden er underkastet naturtvang; ved selv at skabe sin omverden i en stadig omformning af materien skabes blot simulacres falske (gude?) billeder der ikke udtrykker et meningsfuldt absolut, naturen (og gud?). Men det er samtidig evident for enhver, at det moderne samfunds voldsomme exodus fra en natur, hvori den menneskelige omformning spillede en langt mere beskeden rolle, medfører en voldsom synliggørelse af og problematisering af den symbolske formidling mellem individ, samfund og natur.

Derfor kommer kommunikation/repræsentation overfor ekspression også til at bære de stærke ideologiske modsætninger mellem forståelsen af mennesket som et socialt og som et individuelt væsen. Ens vurdering af disse synsvinkler afhænger så af ens egen forhold til det sociale: hvis det er negativt, så understreges kunstens ekspressive aspekt, hvis det er positivt så understreges kunstens kommunikative aspekt. Dominerende kulturelle strømninger i det 20. årh. har trods voldsomme modsætninger været forenet i deres negativitet, såvel f.eks. frankfurterskolens utopiske som de livsfilosofisk-nostalgiske strømninger hr været forenet i oplevelsen af nutiden som en tvangsmæssig fremmedgørelse, som kun negativitet har kunnet bekæmpe. Individerne făr $\mathrm{i}$ højere grad end tidligere deres identitet ved en negation af de sociale værdier og betydninger. Kløften mellem ekspression og kommunikation udspringer derfor også af en historisk udvikling, hvor forholdet mellem afsender, værk, modtager og samfund er undergået kraftige ændringer. Jeg vil uddybe dette i det følgende.

\section{Fra afsender via verk til modtager}

Historisme og biografisme, autonomisme, men også dekonstruktio- 
nisme kan ses som historiske faser $\mathbf{i}$ individualisering og privatisering af det æstetiske konsum. I tidligere tider var den fysiske sammenhæng mellem afsender og modtager reglen, ikke undtagelsen. Dog mere for verbal end visuel kommunikation. Der var derfor ingen grund til at betvivle, at udtrykkene kom fra afsenderen. Og afsenderens indføjning $\mathrm{i}$ en konkret fysisk og social sammenhæng var en konkret virkelighed, som modtageren hele tiden havde for øje i sin fortolkning af udtrykkene. Bevares, ytringerne kunne opfattes som kommende fra f.eks. et guddommeligt andetsteds, man kunne se afsenderen som medium for overnaturlige fanomer, men så netop som medium for budskaber og afsendere der sammenbandt medium og modtager i en kulturel sammenhæng.

Men med opkomsten af bogtrykkerkunst, og senere den enorme mediemæssige eksplosion fra grammofonplade til fotografi, fra bog til film og fjernsyn, er den tidligere konkrete, »naturgroede« sammenhæng mellem afsender og modtager blevet opløst. Afsender og modtager berører kun hinanden i produktet, maleren, fotografen, filmmanden og forfatteren dukker kun op for læseren via sit produkt. Før var der en krop i et miljø, der forankrede udsagnet og modtagelsen.

Derved er produktets udtryksside, kommunikationens fysiske overflade, for alvor blevet synlig og selvstændiggjort i tid og rum. Bogstaver, farver, noder, billedrækker osv. cirkulerer og reproduceres i sammenhænge, hvor der ikke nødvendigvis er oplagte fortolkningsnøgler. På reolen i boghandel, bibliotek eller privathjem kan middelalderlyrik stå ved siden af modernistisk lyrik; en sal med renaissancemalerier kan ligge ved siden af impressionismesalen, der måske igen ligger ved siden af japanske samlinger. Tidslig, geografisk eller afsendermæssig sammenhæng skal møjsommelig rekonstrueres, hvis man da har lyst til det. Hvis man ikke bare vil analysere de rene formmæssige forskelle eller identificere sig med den slentrende besøgende eller con amore-læseren. Som blot stoflighed er de kunstneriske udtryk underbestemte eller ubestemte. Og de kan derfor blive indordnet $i$ en uendelighed af kommunikative bestemmelser. De kan fungere som en udtryksmassig materialesamling for hvemsomhelst. ${ }^{6}$

Historisme og biografisme kan ses som 1. trin af en videnskabelig reaktion på denne løsrivelse af afsender fra udtryk og udtryk fra modtager. ${ }^{7}$ For den positivistiske biograf i det 19. årh. og i begyndelsen af det 20. årh. bestod opgaven i at rekonstruere produktets afsender, i at genopbygge forholdet mellem l'homme og l'Euvre, mellem kunstnerperson og værk. Læseren og seeren mødte kunstværket ude af såvel en individuel som en historisk kontekst. Det gjaldt derfor om at genopbygge den private og historiske kontekst. Dette kunne f.eks. 
ske ved at genskabe renaissancens Italien og dets store kunstnerskikkelser, for derved igen at gøre kommunikationssituationen konkret. Den implicitte eller eksplicitte forudsætning var naturligvis, at den kunstneriske kommunikation, såvel som anden kommunikation, bestod $\mathrm{i}$ at en modtager forstod, hvad en afsender mente, for der var selvfølgelig indkodet en éntydig meddelelse i budskabet. Nøglen til en perfekt forståelse var derfor naturligt nok en historisk rekonstruktion af afsenderen. Biografismen er mundet ud i den historisk-psykoanalytiske kunsttolkning, der har frembragt raffinerede metoder til rekonstruktion af det historiske subjekt, der har produceret det pågældende kunstværk. I det psykoanalytiske synspunkt er der også en åbning mod et funktionalistisk synspunkt, der ikke primært er interesseret $\mathbf{i}$ mening, men i værkets funktion som mediation mellem de forskellige parametre i forfatterens eller læserens livssituation.

Opfattelsen af kunstværket som autonomt kan ses som 2. trin i løsrivelsesbevægelsen. Autonomismeopfattelsen tog fart i begyndelsen af et 20. århundrede. Negativt kan man sige at autonomismen gjorde en dyd af det faktiske fysisk fravær af en konkret afsender. Autonomisterne hævdede nemlig at der ikke var nogen væsentlig sammenhæng mellem afsender og produkt, den kunstneriske skabelsesakt bestod netop i at overskride det personlige og det historiske. ${ }^{8}$ Kunstværket var et system af indre strukturer, der svævede mellem afsender og modtager. Litteraturforskeren Wimsatt og astetikeren Beardsley foretog således et opgør med de to 'fejlagtige' opfattelser, den intentionelle og den affektive. ${ }^{9}$ Kunstværkets strukturer og betydninger var faste og uforanderlige egenskaber ved det specifikke produkt, som modtageren skulle forsøge at analysere sig frem til. Det perfekte kunstværk havde en ubrydelig sammenhæng mellem udtryk og indhold, mellem form og indhold. Kunstværkets rigdom var dets indre strukturelle kompleksitet og betydningsrigdom, ikke dets forbindelse til omverdenen.

Var modtageren - ifølge autonomi-tilhængerne - ikke i stand til at komme på talefod med afsenderen, så var han i det mindste i stand til at komme på talefod med værket, der jo sansekonkret var foran næsen. Med de poststrukturelle synspunkters fremmarch indvarsles et 3 . trin i løsrivelsen af teksten fra dens indføjning i konkrete og relativt afgrænsede kommunikationssammenhænge; nu må læseren næsten også give afkald på en kontakt med værket. De kan ganske vist komme i kontakt med værkets stoflighed, dets udtryk, Men der er ingen guddommelig instans, der sikrer en sammensvejsning af udtryk og indhold. Udtrykkene er kun betydningspotentialer for læseren, de er flydende betydere, floating signifiers. Den amerikanske litteraturfor- 
sker Lentricchia har i After the New Criticism (1980) ironisk sammenlignet denne opfattelse af værket som svarende til funktionen af de ubestemte klatter i en Rorschack-test, der fremkalder patientens associationer. Når man ser et værk, er man fundamentalt overladt til den private association, selvom nogle talspersoner for denne opfattelse vil specificere bredere eller smallere sociale rammer for hvad der er en rimelig og hvad der er en 'urimelig' betydningsfluktuation.

Enhver drøm om at kunne forstå afsenderen eller værket, kan man godt lægge på hylden. Til gengæld kan man nu i højere grad glæde sig over egen rigdom, for teksterne er kun de ydre stoflige anledninger til betydningsarbejdet; i den radikale version er laseren selv forfatter, der med anledningen i tekstens udtryk skriver sine egne værker.

For Barthes er forholdet mellem kommunikation og ekspression, mellem afsender og modtager, tendenser i de enkelte tekster. Der er på den ene side ideologiske træk i værket, der hævder identitet, mening og repræsentation, og som derfor forsøger at formidle et budskab. Men der er på den anden side andre, uideologiske og frigørende træk i teksten, der bygger på free play, på associationernes og oplevelsernes frie spil. De laselige tekster hælder mest mod den kommunikativt-ideologiske pol, de skrivbare tekster hælder mest mod den ekspressive, uideologiske pol ${ }^{\text {lo }}$

Det problematiske $\mathrm{i}$ dette synspunkt består i at forsøge at forankre henholdsvis en afsender-kommunikationssynsvinkel og en modtagersynsvinkel i tekstinterne forhold fremfor i kommunikationssynsvinklen og i de læsemål den enkelte læser sætter sig. Det er en smal sag at finde budskaber i de eksistentialistiske tekster, som Barthes tror er et skriftens ideologiske nulpunkt. Og det er lige så let at læse gamle billeder og litteraturværker udfra den private associations princip eller udfra en systematisk 'uhistorisk' moderniserende læsning.

Når læsningen rykker i forgrunden har det selvfølgelig en sammenhæng med at stadig flere æstetiske produkter formidles anonymt og modtages af personer, der kun gør sig vage forestillinger om en afsenderinstans. Derved synliggøres modtageren, forbrugeren, som den der umiddelbart er bærer af værkernes betydning. Enkeltværket opnår ikke værkkarakter, det er en del af en strøm af værker. Den enkeltes modtagelse af værker sker under former, der har meget lidt til fælles med den intense nærlæsning af det enkelte, autonome værk. Afsender-værkstrukturen bliver dermed blot et potentiale i læsningen, og i hvor høj grad dette potentiale realiseres, afhænger helt af om læseren har et erfarings- og kontekstfællesskab med afsenderen.

En hastig voksende forskning, der går under navnet receptionsforskning, forsøger at foretage en videnskabelig kortlægning af de sociale og 
individuelle betingelser, hvorunder modtagelsen, læsningen, af tekster foregår. Her gør man sig ikke filosofiske forestillinger om teksten, men foretager konkrete undersøgelser af enkelte modtageres eller grupper af modtageres læsninger af kunstværker, og anstiller betragtninger over årsagen til, at de enkelte læsninger falder ud som de gør. Én kilde til receptionsforskning har været ønsket om at genskabe et givet værks læsning $\mathrm{i}$ en historisk tidligere periode (således f.eks. i litteraturforskningen Jauss og delvis Iser), en anden kilde har været marketingsønsker om at udfinde grundene til givne produkters modtagelse og salg.

En forståelse af, hvilke betydninger afsenderen har indlagt og med hvilket formål og hvilken funktion, vil hyppigt være en værdifuld nøgle til forståelsen af især de mere ubevidste aspekter af receptionen. Selv for professionelle vil det hyppigt være vanskeligt og tidsrøvende at redegøre for deres reception af et givet værk, og sandsynligvis vil en normal modtager kun kunne redegøre for en lille del af den fascination og de betydninger som receptionen fremkalder. I princippet involverer hver læsning en aktualisering af et livs erfaringer og læreprocesser, og kun en brøkdel af disse er bevidst i receptionen.

\section{Historisme - socialhistorie - mentalitetshistorie}

Såvel de strukturelle som de poststrukturelle og receptionsmæssige synspunkter tenderer til enten at interessere sig for tekstinterne eller læserinterne strukturer og funktioner. Det banale synspunkt, at selv æstetiske teksters betydning og funktion kun fuldt kan forstås i forbindelse med deres indgåen i større livssammenhænge, er hovedsageligt blevet forfægtet af de historiserende og psykoanalytiske retninger i kritikken. Disse er, som ovenfor anført, historisk udsprunget af ønsket om rekonstruktionen af en afsender og en afsenderkontekst. Og derved udtryk for ønsket om rekonstruktionen af de sammenhænge, der var forudsat i tidligere tiders banale opfattelse af, at liv og værk hang sammen, omend ikke nødvendigvis på en direkte, afspejlende måde.

En del af kritiken af historismen tog sit udgangspunkt $i$, at den havde for forenklede forestillinger om denne sammenhæng mellem liv og værk. I mere skærpet form blev kritikken til en generel benægtelse af en determination fra liv til værk. Dels udfra metodiske synspunkter, men dels også udfra mere ideologiske synspunkter, der så en forbindelse mellem liv, samfund og værk som en underkendelse af kunstnerens evne til fri skaben og selvekspression. I historismens 
strengeste udgaver havde kausalrelationerne fra liv til værk ikke alene karakter af, at livsomstændighederne var nødvendige forudsætninger for forklaringen af værkerne og deres betydninger, livsomstændighederne var også tilstrækkelige betingelser. Historismens modstandere tog hyppigt udgangspunkt i denne strenge, totaldeterministiske version, ikke mindst fordi historismen i det 20. årh.s anden halvdel hyppigt kun er overlevet i en særlig hegelsk-marxistisk variant, hvor determinismen samtidig er knyttet sammen med en finaldetermination, historien styrer frem mod et bestemt mål, den er ikke blot led i en åben kæde af årsagsforhold. Den konsekvente historisme er dog ikke af denne type. Den tager sit metodiske udgangspunkt $i$ at historien er en åben struktur, hvor de enkelte historiske trin udgør et mulighedsfelt, nogle nødvendige men ikke tilstrækkelige forudsætninger for kulturens videre udvikling.

Konsekvensen af at hævde, at kunstværket er autonomt og uden forbindelser til liv og samfund er selvfølgelig, at det kun kan handle om sig selv. Og det var da også en konsekvens som såvel en række modernistiske kunstnere som en rakke (strukturelle og) poststrukturelle teoretikere i princippet drog. I praksis er det selvfølgelig vanskeligt helt at få uddrevet enhver repræsentation af ikke-immanente elementer. Og under alle omstændigheder var de finkulturelle selvrefleksive metaprodukter relativt isolerede øer i såvel den kulturelle hovedstrøms som massekulturens mere repræsentative hav. Man kan synes at kunsten som blot selvrefleksion er en altfor beskeden rolle, og modsiges af den stadig stigende rolle som de symbolske systemer spiller i det sociale liv. Selvrefleksionsholdningen kan da også ses som udtryk en fortrængning af fraværet af enhver form for metafysisk garant for fremstillingen; der er ingen absolut gud eller natur at forankre værket $\mathrm{i}$, hvorfor fremstillingen nødvendigvis bliver en produceret mediation af individ og omverden. Autonomisynspunktet og selvreflektionssynspunktet kan derfor ses som bastioner for hævdelse af et vesen, en essens løsrevet fra historicitetens og subjektivitets relativisme.

Svarende til modtagersynspunktets fremmarch i forståelsen af enkeltteksten, har der i de senere årtier været markeret tilsvarende synspunkter på historien og på større tekstmængder. Ud fra dette synspunkt er 'de store historier', de store sammenhænge, konstruktioner, som den enkelte forsker skaber, næsten på samme måde som skrev han en roman. Historisk forskning er således nærmest en litterær genre, som mest må forstås udfra dens æstetiske og politiske brugsværdi for forskeren. " Rigtigt er det selvfølgeligt af historiske fremstil- 
linger altid skrives $\mathrm{i}$ retrospekt, og at vanskelighederne ved at finde objektivismens olymp er mangfoldige. Årtiers kritik af forskningens interessestyrethed har forfinet forståelsen af den stadige idcologisering. ${ }^{12}$ Det er måske ikke underligt, at forskere kan fă den idé, at historien er æstetik og fiktion, når de sidder bøjede over fortolkningsarbejdet. Men når de forlader bibliotckerne, vogter de sig for at køre over for rødt, og bestræber sig for at opdrage deres børn. I deres egen livspraksis tror de, med god grund, på kausalsammenhænge, på objektive historiske sammenhænge. De praktiske problemer ved udforskningen af kulturhistorien, der hyppigt forøges med forøget kulturhistorisk viden, er ikke et videnskabeligt argument mod historismen. De store historier, lever bedre end nogensinde, og de bliver $i$ stigende grad facetteret og profileret af en mangfoldighed af mindre historier.

Hyppigt har diskussionen af sammenhængen mellem liv, samfund og værk udspillet sig $i$ et mellemfelt mellem hævdelsen af værkets totalc autonomi og hæudelsen af dets totale heteronomi. Dette mellemfelt består især i at bekræfte værkets sammenhænge med meget nære og personlige fænomener og fornægte sammenhæng med merc fjerne og upersonlige. F.eks. accepteres det, at værket forholder sig til aspekter af det private liv, til følelser som glæde og sorg, eller til bestemte sansninger, eller forholder sig til abstrakte opbygningsprincipper, balance, symmetri osv. hvorimod sammenhænge på mere overordnede sociale og historiske planer benægtes, da det ville begranse muligheden for fri, dvs. privat selvekspression og henvise enkeltindividet til en mere ydmyg placering $i$ den sociale helhed og $i$ det historiske forløb. Omvendt vil historiserende synsvinkler hyppigt vægte fremstillingen af de generelle, sociale aspekter og underbetone de selvekspressive elementer.

Et andet kompromis mellem afspejling og autonomi blev navngivet med Althusser's begreb om relativ autonomi. De æstetiske former har stof- og formspecifikke strukturer o.s.v., men samtidig indgår de i komplekse funktionsforhold med den øvrige virkelighed. Og hensigten med en række nyere socialhistoriske og mentalitetshistoriske fremstillinger af æstetisk-symbolske tekster er netop at vise, hvorledes disse er bestemte funktionelle formninger af forholdet mellem liv og samfund. Funktionalisme er egl. indenfor humanvidenskaberne en retning inden for antropologicn, og via f.eks. antropologen LéviStrauss - der ganske vist selv personligt ville have frabedt sig at blive kald funktionalist - trængte synspunktet ind i tekstanalyse. Men også psykoanalysen var et reservoir for funktionalistiske synspunkter. Den freudske psykoanalyse var ganske vist i sit udgangspunkt herme- 
neutisk, men Freud bevægede sig mere og mere i en funktionalistisk retning. Med funktionalistiske synspunkter vil jeg her forstå synspunkter, der ikke kun stiller hermeneutiske spørgsmål: hvad betyder dette, og heller ikke stiller afspejlingsteoretikerens spørgsmål: hvad forestiller dette, men derimod stiller spørgsmålet: hvilken funktion har dette.

Det funktionalistiske synspunkt vil - som det kommunikative synspunkt - umiddelbart kunne opleves som en dementi af værkernes ekspressivitet. Selvom en funktionalistisk beskrivelse også inddrog subjektets rolle som begrunderen af betydning, da betydning altid er betydning for et menneskeligt subjekt, kan den videnskabelige objektivering opfattes som en krænkelse af enkeltindividets inderlighed og almagt. Til gengæld muliggør den videnskabelige funktionalisme en omfattende redegørelse for, hvorledes de æstetisk-symbolske værker ikke er marginale tidsfordriv, men derimod centrale mentale værktøjer. De indgår på stadig mere central vis $i$ menneskets dannelse, hvis man med dannelse ikke bare forstår en passiv tilpasning til den sociale helhed men også en aktiv-processuel historisk selvkonstruktion, en aktiv evolution.

Afslutningsvis vil jeg bemærke, at mine betragninger ikke skal ses blot som et oplæg til metodemæssig pluralisme, forstået som dette er godt men hint er også meget godt. Men derimod som et oplæg til en metodisk holisme, forstået som en skærpet bevidsthed om hvilke antagelser og hvilket anvendelsesmæssigt omfang forskellige metodiske tilgange har, og derved en skærpet forståelse af på præcis hvilken måde de supplerer hinanden. De næste tiårs teori- og metodeudvikling vil efter alt at dømme mere få karakter af videreudbygning af eksisterende tilgange, end opfindelsen af nye. Men netop i den metodiske syntese og metodiske supplering ligger der efter min opfattelse mange frugtbare muligheder for fornyede indsigter i kendte problemstillinger og metoder. Vi kan således benytte historisme, mentalitetshistorie, strukturalisme, poststrukturalisme, receptionsteori, hermeneutik, psykologisme osv. til indbyrdes supplering.

Ovenstående artikel er en let revideret udgave af en indledningsforelæsning til en række forskeruddannelsesseminarer i fiktionsteori for de litterære og musisk-æstetiske fag, støttet af Forskerakademiet.

\section{Noter:}

1. Med subindividuel forstår jeg her det forhold, at grammatologien beskxftiger sig med forskelle m.v., der ligger langt under det niveau, hvorpå 'jeg' og individualitet er defineret, men hvor disse forskelle samtidig tænkes indenfor en individucl bevidsthedsproblematik. 
2. Individuel her selvfølgelig ikke forstået $\mathbf{i}$ en 19. årh.s. betydning med et centreret jeg, men derimod blot som markering af et forhold mellem én bevidsthed og nogle udtryksmidler, stemmebånd, skrivemaskine, pensel, kamera.

3. Saussure's udsagn om at sproget var et system af forskelle uden positivt indhold var primært tænkt som et udsagn om udtrykssystemet, og den senere brug af udsagnet til også at omfatte indholdssystemerne fik hyppigt en delvis metaforisk karakter.

4. Derrida udgår fra et religiøst, jødisk miljø, og for ham, som for mange andre 'poststrukturalister', har kampen mod logos, mod de fikserede betydninger, varet led i forsøget på en frigørelse fra en religiøs og autoritær verden. En stor del af hans forskning har derfor været mere rettet mod at påvise de ideologiske begrundelser for givne tekstteorier - den store gud logos - end at beskrive deres funktion i forhold til verden og samfund. I de senerste år kredser hans tanker i stigende grad om snævert religiøse problemstillinger.

5. Og da betydning er et socialt fænomen, betyden et individuelt, har de derfor særligt beskæftiget sig med den betydningsløse, dvs. ikke-præciserbare betyden, der fungerer for denne betydens socialisering, beskæftiget sig med de små differencer og forskydninger, der i den sociale kommunikation bestemmes og făr betydning.

6. Den amerikanske litteraturteoretiker Harry Bloom har i A Map of Misreading [Oxford 1975) søsat begrebet 'misprision', der skal dække over fænomenet den konstruktive misforståelse. En given modtager konfronteres med nogle udtryk, og da en kommunikativ opbygning af intersubjektiv identitet altid er mangelfuld, 'misforstår' modtageren teksten, bruger udtrykkene som et materiale til produktion af et nyt værk. Set på denne måde bliver kulturudviklingen én lang kæde af konstruktive misforståelser.

7. Der har rødder i 'førvidenskabelige' reaktionsmåder, særlig i form af den kristne hermeneutik. Mens den klassiske æstetik, f.eks. Aristoteles, i høj grad var en teoretisering over praksis, over midler i kommunikationen, var den kristne hermeneutik centreret omkring konstruktionen af den rette betydning af de hellige tekster, dvs. rekonstruktionen af deres betydning for afsenderen, gud.

8. Kunstneren tilpassede sig også derved til et heterogent marked, hvor en for konkret forfatterperson kunne indskrænke varkets udbredelse til forskellige grupper.

9. I artiklerne 'The Intentional Fallacy' og 'The Affective Fallacy' optrykt i deres The Verbal Icon 1954.

10. Se således Barthes: $S / Z$ [Paris 1970].

11. Jr. f.eks. den amerikanske historiker Hayden White's positioner.

12. Men samtidig er denne kritik hyppigt blevet fremført af personer, der har stået på en teleologisk historieopfattelse, og ikke har videreført den sterke udgave af det 19. arh.s historiske materialisme, der ser historien som en åben proces. 